\title{
Некоторые вопросы генетической классификации дардских языков по данным исторической фонетики
}

\begin{abstract}
Генетическая классификация дардских языков до недавнего времени оставалось во многом неясной. В частности, не получил убедительного ответа вопрос о наличии восточнодардской подгруппы. Проведенное недавно исследование восточнодардского лексического материала в рамках усовершенствованного лексикостатистического метода показало, что восточнодардские языки, несомненно, составляют генетически единую языковую общность. В настоящей статье делается попытка выделить общие для них историко-фонетические инновации. Автору удалось обнаружить пучок из четырех изоглосс, явно отличающих восточнодардские языки от всех прочих дардских. Хотя часть этих изоглосс затрагивает и другие языки региона (индоарийские и иранские), весь пучок целиком не встречается нигде за пределами восточнодардской подгруппы.

Ключевые слова: генетическая классификация языков, историческая фонетика, дардские языки, арийские языки.
\end{abstract}

Несмотря на то что сравнительно-историческое изучение дардских языков имеет достаточно давнюю историю, внутреннее членение дардской языковой общности всё еще остается неясным. Наглядным проявлением этого факта является отсутствие общепринятой генетической классификации: до сих пор исследователям приходится иметь дело с двумя альтернативными классификационными схемами. Первая из них, предложенная в начале минувшего века Дж. Грирсоном [Grierson 1919], показана ниже на рис. 1. Впоследствии эта классификация неоднократно подвергалась критике. И хотя критика нередко была справедливой и заставляла существенным образом корректировать конфигурацию родословного древа ${ }^{1}$, взгляды Дж. Грирсона, как будет показано далее, в целом ряде аспектов не утратили актуальности в настоящее время и поэтому никоим образом не должны полностью отбрасываться как устаревшие. Вторая классификация была предложена Г. Моргенстьерне и позднее несколько откорректирована Р. Стрендом [Morgenstierne 1961; Strand 1973; 2006]. Она отличается большим количеством ветвей (см. рис. 2), а также их статусом: Г. Моргенстьерне рассматривал дардские языки как индоарийские, утверждая при этом, что они не образуют генетически единой подгруппы внутри индоарийской группы.

Обе приведенные классификационные схемы являются во многом интуитивными и далеко не всегда опираются на строгие сравнительно-исторические критерии. Неслучайно исследования последних лет показали, что некоторые идеи, высказанные как Дж. Грирсоном, так и Г. Моргенстьерне, не могут быть приняты. Это, в частности, относится и к утверждению об отсутствии дардской языковой общности и принадлежности дардских языков к индоарийской ветви. Данные исторической фонетики, лексико- и этимо-

${ }^{1}$ В частности, была убедительно показана невозможность предлагавшегося Дж. Грирсоном включения в дардскую группу нуристанских («кафирских») языков [Morgenstierne 1926; 1932; 1945; 1961; Buddruss 1977; Strand 1973; 2006; Edelman 1983; Эдельман 1992].

Journal of Language Relationship • Вопросы языкового родства • 13/1 (2015) • Рp. 1-21 • ( С Коган А. И., 2015 




Рuс. 1. Классификация языков дардской группы по Дж. Грирсону

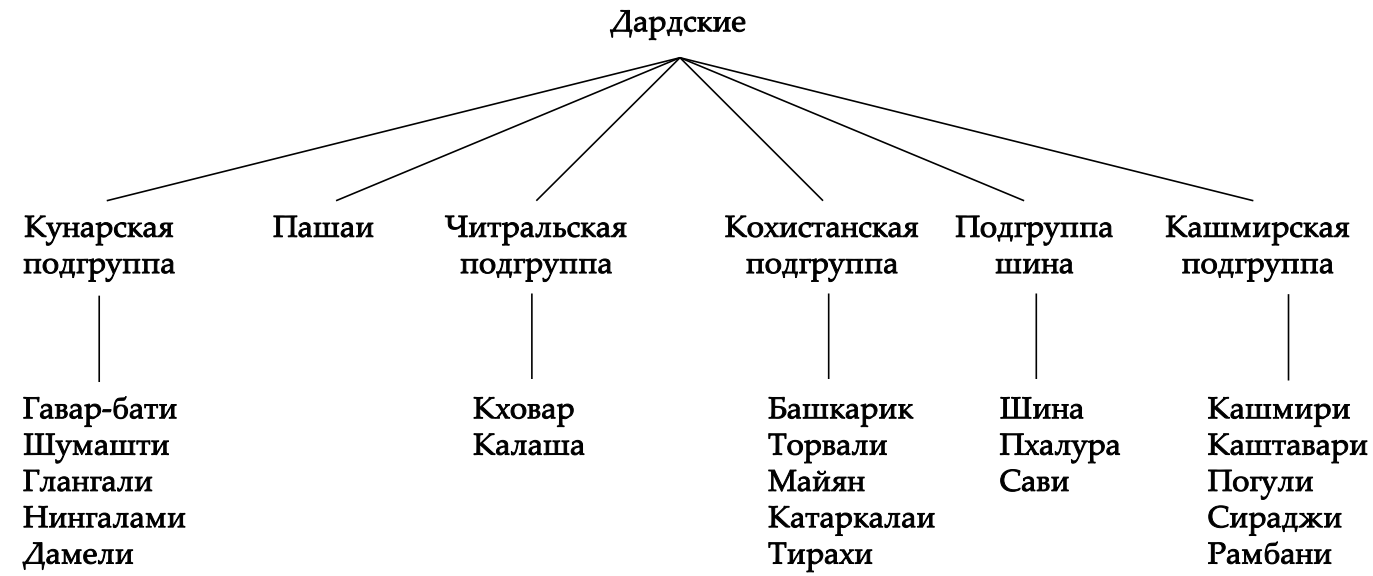

Рuc. 2. Классификация языков дардской группы по Г. Моргенстьерне

статистики свидетельствуют о том, что дардская общность, несомненно, носит генетический характер, а ее обособление относится ко времени распада индоиранского единства [Коган 2005]. Интуитивный характер существущих классификаций и недоказанность целого ряда их положений заставляют вновь вернуться к вопросу о филиации дардской языковой общности.

В нашей недавней работе [Васильев, Коган 2013] этот вопрос был рассмотрен с позиций лексикостатистики. Результаты лексикостатистических подсчетов обрабатывались в соответствии с двумя альтернативными методиками: методом ближайших соседей, используемым в системе Starling, и разработанным М. Е. Васильевым методом наименьших средних отклонений (подробное описание этого метода см., например, в [Васильев, Коган 2013]). Два родословных древа, построенных в соответствии с этими методами, приводятся на рис. 3 и 4. 







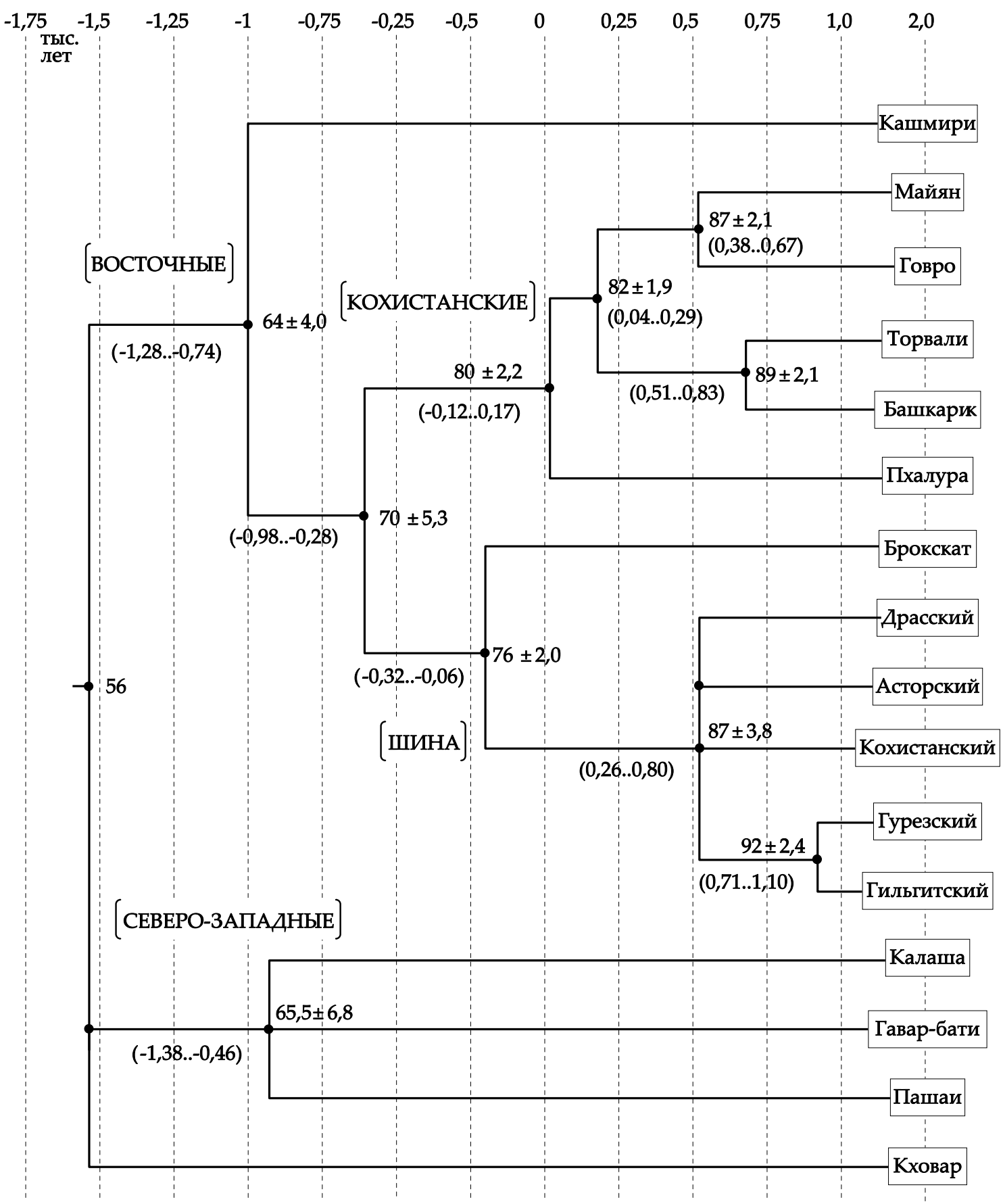

Рuc. 4. Родословное древо дардских языков, построенное методом наименьших средних отклонений

Как можно видеть, классификационные схемы, полученные нами с использованием двух разных методик, оказываются практически идентичными. Кроме того, обращает на себя внимание близость этих схем к классификации Дж. Грирсона. Пожалуй, наиболее важным пунктом, в котором они сближаются с последней, противостоя при этом классификации Г. Моргенстьерне, является статус восточнодардской языковой общности. Эта общность, включающая кашмири, диалекты шина и кохистанские языки (башкарик, торвали, майян, говро, чилиссо), постулировалась Дж. Грирсоном как 
генетическая ${ }^{2}$, однако не признавалась Г. Моргенстьерне. При этом открытой полемики по данному вопросу между учеными по непонятным причинам не велось. На приведенных выше родословных деревьях все идиомы, традиционно причисляемые к восточнодардским ${ }^{3}$, составляют единую ветвь, отличающуюся, впрочем, достаточно длительным периодом дивергенции (более двух тысяч лет). Данный факт не только вносит существенную ясность в «восточнодардскую проблему», но и, несомненно, свидетельствует о гениальной интуиции Дж. Грирсона, предвосхитившего столетие назад результаты, полученные с применением современных компаративистских методов.

Было бы, однако, неоправданным утверждать, что в вопросе о генетических отношениях восточнодардских языков полностью устранены все темные места. Как известно, идиомы, образующие единую генетическую общность, как правило, обнаруживают общие классифицирующие черты на разных уровнях языковой системы. Наиболее показательными при этом чаще всего считаются историко-фонетические изоглоссы. Поэтому в ситуации, когда достаточно тесное родство восточнодардских языков представляется весьма вероятным, естественным было бы попытаться выявить общевосточнодардские классифицирующие инновации в исторической фонетике.

Первая и, по-видимому, единственная такая попытка была сделана Г. Буддруссом. В работе, посвященной языку катаркалаи, он называет три фонетических перехода, являющиеся, на его взгляд, специфически восточнодардскими: * $\mathrm{w}>\mathrm{b}$, *st > t(h) и *șt > ț(h) [Buddruss 1960: 71-72]. Более детальный анализ материала, однако, показал, что только второе из перечисленных звуковых изменений может претендовать на общевосточнодардский статус [Васильев, Коган 2013]. Переход *st > th) затрагивает прежде всего древнюю интервокальную позицию ${ }^{4}$ причем наиболее архаичным (вероятно, общевосточнодардским) рефлексом интервокального кластера *st является гемината th [там же]. Показательно, что в дардских языках, не относящихся к восточнодардской подгруппе, данное развитие не встречается. При этом, однако, оно хорошо известно в истории индоарийского, где отмечается начиная со среднеиндийской эпохи [Woolner 1917: 19]. Поэтому, как мы уже указывали [Васильев, Коган 2013], рассматриваемое явление может носить ареальный характер, и его нельзя считать решающим аргументом в пользу тесного генетического родства. Кроме того, для сколько-нибудь надежного обоснования такого родства желательно наличие не одной единственной изоглоссы, а пучка изоглосс.

Выйти из положения в данном случае можно было бы, привлекая для анализа бо́льшее число историко-фонетических фактов. Признавая неудачу попытки Г. Буддрусса, мы, тем не менее, не видим оснований считать выявление общевосточнодардских инноваций в исторической фонетике неразрешимой задачей. В случае если их удастся обнаружить, можно будет гораздо более определенно говорить о генетических отношениях восточнодардских языков, нежели это позволяет нынешний уровень знаний.

Фонологические системы большинства языков, относимых к восточнодардской подгруппе, довольно архаичны в сравнении с общедардским состоянием. Из относительно немногочисленных историко-фонетических изменений, затронувших древние одиночные фонемы, по-видимому, ни одно не может претендовать на общевосточнодардский

${ }^{2}$ К восточнодардским, помимо перечисленных выше, относят также неизвестные Дж. Грирсону языки пхалура (с диалектом сави) и катаркалаи.

3 Точнее говоря, все традиционно причисляемые к восточнодардским идиомы, по которым удалось собрать стословные списки. Два предположительно восточнодардских языка - катаркалаи и чилиссо остались за рамками нашего исследования ввиду крайнего недостатка материала.

${ }^{4}$ Примеры см. в [Васильев, Коган 2013]. 
статус. Гораздо больше общего, однако, наблюдается в отражении старых консонантных кластеров. Кроме уже рассмотренного Г. Буддруссом сочетания *st (см. выше), к таким кластерам относится группа *śr, а также ряд групп с начальным носовым.

Древняя консонантная группа *śr (< и.-e. * k'r, *k'l), как правило, отражается в восточнодардских языках в виде церебрального ș или в виде регулярных более поздних его рефлексов: кашм. šāy 'место, пристанище' (̌̌ < ‘ṣ) при шина șū 'отдых', șoiki 'прикреплять, прикладывать', башк., май. șā- 'надевать', пхал. șūm '(я) надеваю’, паш. șe'приставать, быть прикрепленным', др.-инд. śraya- 'пристанище', śrayati 'кладет, помещает’; шина șomoiki 'уставать', др.-инд. śrāmyati ‘устает’; торв. șā 'голова' < *śrāya[Turner 1966: 736]; торв. șō 'рог’ при авест. sru- с тем же значением; кашм. оš, шина аșu, торв. aș 'слеза' при др.-инд. аśru- с тем же значением, авест. asrū 'слезы'; кашм. haš, торв. paiș, шина šăș 'свекровь’ при др.-инд. śvaśrū, др.-ир. *xvaśrū- > кл.-перс. xvašū, пушту xvāșa с тем же значением; шина mișoiki 'смешивать', mișillu 'смешанный’ при др.-инд. miśrayati ‘смешивает’, miśrita- 'смешанный’; пхал. bișamilo 'отдохнувший', сави beșåmo 'медленный’ при др.инд. viśramate 'отдыхает’; май. așing 'hollow of the knee' < *āśrōṇikā- [Zoller 2005: 72], gōṣuil 'cowshed' < *gōśraya-kula- [Zoller 2005:148], говро șaynār 'tendon at hollow of the knee’ при др.-инд. śrōni- 'ягодица', snāru- 'сухожилие' [Zoller 2005:388]. Исключения довольно немногочисленны и в большинстве своем объясняются относительно вторичными историко-фонетическими процессами. Так, в башкарик и майян отмечены примеры š вместо ожидаемого ș после гласного $i$ : башк. bišim- 'отдыхать', bišom 'отдых’ при др.-инд. viśramate 'отдыхает', май. miš 'with' [Zoller 2005: 338] при др.-инд. miśrita- 'смешанный'. Вероятнее всего, в этих примерах имела место палатализация более старого церебрального, обусловленная благоприятной позицией в слове. Башк. assun 'слеза', по-видимому, представляет собой заимствование из какогото невосточнодардского языка (ср. кал. āstru, г.-б. an $\lambda u k$ < *ãstruk с тем же значением). В май. а̃с̣̌ 'слеза' появление конечной аффрикаты, вероятно, произошло вследствие аналогии с а̃ с̣̆(h) 'глаз’.

Нерегулярное историко-фонетическое развитие характерно в некоторых языках для этимологических соответствий др.-инд. śvaśrū и др.-ир. *xvaśrū- 'свекровь': пхал. preș,

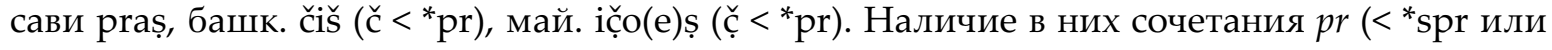
*špr) или его закономерных рефлексов указывает на имевшую место в прошлом дардскую метатезу - появление согласного $r$ в позиции после начального согласного (или последнего согласного начального кластера) под влиянием конечного сочетания типа $\mathrm{Cr}$ или rC. Поскольку в этимологически родственных словах кашмири и шина (haš и šăș coответственно) следов метатезы не обнаруживается, ее нельзя считать общевосточнодардским явлением. Таким образом, приведенные здесь примеры из пхалура, сави и кохистанских языков можно было бы рассматривать как свидетельство того, что древняя группа *śr в течение определенного времени сохраняла в этих языках свой второй компонент, а, следовательно, реконструкция ее общевосточнодардского рефлекса в виде *s невозможна. Однако, поскольку данный тип историко-фонетического развития обнаруживается лишь в одном слове и при этом сосуществует с переходом *śr > ș в других словах, речь может идти именно о перебое в звукосоответствиях, требующем объяснения. Наиболее правдоподобным объяснением, на наш взгляд, является заимствование или фонетическое уподобление родственному слову другого дардского языка. Таким языком мог являться, например, калаша или кховар, где в названии свекрови (кал. ispres, кхов. išpreši) также обнаруживается дардская метатеза, причем сохранение древнего $\mathrm{r}$ в обоих языках, по всей видимости, регулярно (см. ниже). Влияние на пхалура и кохистанские языки со стороны кховар и калаша представляется нам вполне возможным, поскольку 
два последних языка распространены в области Читрал, находящейся непосредственно к северу от Кохистана. В этой же области расположен и ареал языка пхалура5

Переход *śr > ș отмечается не только в языках, традиционно причисляемых к восточнодардским. Однако, по-видимому, нигде за пределами предполагаемой восточнодардской подгруппы он не является фронтальным. Так, в калаша он отмечается в начале слова (ср. кал. șadar 'слуга' при др.-инд. śraddhālu- 'верный' [Morgenstierne 1973ㄹ: 143]; кал. (уртсунский диал.) șeĩ 'голова' < *śrāya- [Turner 1966:736], если это не заимствование из языка кати [Morgenstierne 19731: 143)6, в то время как в интервокальной позиции (как исторической, так и возникшей вторично) древняя группа śr отражается как str: āstru 'слеза' при др.-инд. aśruс тем же значением, авест. asrū 'слезы’; ustru ‘бедро' при др.-инд. śrōni- 'бедра, ягодицы, филейная часть', авест. sraoni- 'бедро, ягодица'7. Во многом близкая ситуация наблюдается в пашаи. Там в начальном положении *śr отражается как ș, а интервокальном - как yr или ir (ср. șe- 'привязаться, пристать' < *śraya-, др.-инд. śrayati 'располагается'; șenī 'взрослая (о девушке)' при др.-инд. śrayanīya- 'нуждающийся в пристанище’ [Morgenstierne 1956: 171]; äirik 'слеза' при др.-инд. aśru- с тем же значением, авест. asrū 'слезы'; šairū 'свекровь' при др.-инд. śvaśrū-, др.-ир. *xvaśrū- > кл.-перс. xvašū, пушту xvāṣa с тем же значением) ${ }^{8}$.

Ситуация в кунарских языках остается не вполне ясной из-за крайнего недостатка материала. Примеры рефлексов группы *śr как в начальной, так и в интервокальной позиции имеются лишь в одном языке - гавар-бати. Здесь ситуация, по-видимому, близка к таковой в языке калаша. Начальное *śr отражается в виде ș (cp. șa- ‘ударять; посылать' < *śrāyaya- [Morgenstierne 1950: 51], др.-инд. śrayati 'располагается’'), а интервокальное - в

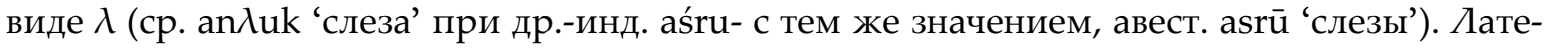
ральный $\lambda$ является регулярным отражением древней группы *tr [Morgenstierne 1950: 12], а возможно, также и группы *str в интервокальном положении. Таким образом, интервокальное развитие в гавар-бати, несомненно, отличалось от восточнодардского и не приводило к появлению церебрального сибилянта.

В языке кховар древнее сочетание *śr, по всей видимости, сохраняется в неизменном виде как в начальной, так и в интервокальной позиции (ср. šrōn 'ягодицы, бедро' при др.-инд. śrōni- 'бедра, ягодицы, филейная часть', авест. sraoni- 'бедро, ягодица'; ašrū 'слеза' при др.-инд. aśru- с тем же значением, авест. asrū 'слезы’)10. Таким образом, кховар в данном отношении является наиболее архаичным языком дардской группы.

Из всего сказанного выше нетрудно сделать вывод, что только в тех языках дардской группы, которые традиционно причисляют к восточнодардским, развитие *śr > ș

${ }^{5} \mathrm{~K}$ языку пхалура весьма близок сави, распространенный, однако, западнее - на востоке Афганистана в окружении носителей языка гавар-бати и испытавший значительное влияние последнего [Buddruss 1967]. Исходя из географического положения сави, можно с большой долей вероятности предположить, что в свой нынешний ареал этот язык был занесен мигрантами из области распространения пхалура, т. е. из Южного Читрала.

${ }^{6}$ Имеется также пример перехода *śr > š: šiț 'лестница' < *śrișța- [Morgenstierne 1973: 143]. Начальный палатальный сибилянт в этом примере, возможно, возник из более раннего церебрального в результате диссимиляции [там же].

${ }^{7}$ См. также [Morgenstierne 1973:200-201]. Цитировавшаяся выше форма ispres 'свекровь' также, возможно, развилась из более раннего *ispestr с последующей дардской метатезой.

${ }^{8}$ О развитии древней группы *śr в пашаи см. также [Morgenstierne 1967: 38, 40]. Переход *śr > yr, вероятно, как-то связан с перехода древнего неначального ś в y. Об этом переходе см. [Morgenstierne 1967: 33].

9 В г.-б. šouțo 'голова' < *śrāya- [Turner 1966: 736] начальный палатальный сибилянт, возможно, возник из более раннего церебрального в результате диссимиляции, вызванной наличием позднего суффикса ț.

${ }^{10}$ См. также [Morgenstierne 1947: 7]. 
характерно для всех позиций в слове. Во всех остальных языках оно либо приурочено к анлауту, либо отсутствует вовсе. Поэтому данный переход можно считать, сделав оговорку о его фронтальном характере, общевосточнодардской историко-фонетической изоглоссой.

Весьма близким является поведение в восточнодардских языках старых интервокальных консонантных групп с начальным носовым. Если второй (следующий за носовым) согласный в такой группе в древности был глухим, в современных рефлексах он, как правило, озвончается (ср. кашм. andar 'внутри, в', әndir 'кишка, кишечник', әndrim 'внутренности', торв. andarē 'в доме', май. and $\mathrm{rmās}$ 'диафрагма (букв. «внутреннее мясо» $\left.{ }^{11}\right)$ ', ã̃ $\left(z<{ }^{*} \mathrm{dr}\right)$ 'кишки', шина (кохистанский диал.) аұ̣o 'внутри', эұ̣i 'внутренности' $(\mathrm{z}<* \mathrm{dr})$ при др.-инд. antar- 'внутри', antara- 'внутренний', āntra- 'внутренности', авест. antarə 'внутри', antara- 'внутренний'; кашм. dand 'зуб', башк. dındə при др.-инд. dant-, danta-, авест. dantan- с тем же значением; кашм. gond 'пучок, букет', ganḍ 'узел', ganḍ'связывать, завязывать', пхал. grhēṇ̣ 'узел', башк. gäṇ̣-, торв., май., gaṇ̣-, пхал. ghāṇd'связывать, завязывать' при др.-инд. grantha-, granthi- 'узел', granthayati 'связывает, завязывает’, хот.-сак. grantha- 'узел'; кашм. mand- 'сбивать (например, масло), взбивать; расплескиваться’, башк. mad-, май. ma(n)d-, торв. mand(h)-12 'сбивать масло’, батери madhã 'мутовка' при др.-инд. manthati 'взбалтывает, сбивает масло, трет, растирает', manthāna'мутовка', хот.-сак. mamth- 'сбивать масло'; кашм. wandi, сави hemand 'зима' при др.инд. hemanta- то же; кашм. yendar 'прялка', башк. yãl $(1<* d r)$, май. yã̃ $(z<* d r)$, пхал. yāndr 'мельница' при др-инд. yantra- 'устройство, приспособление; ручная мельница'; кашм. kanguw 'мужской гребень', kangin' 'женский гребень', башк. kēnig, торв. kyäng, май. kang, пхал. khyēnigia, kēṅgī, сави khyēngiā, шина kōn்i 'гребень' при др.-инд. kan்kata- с тем же значением ${ }^{13}$; кашм. inz 'гусь', шина hănza при др.-инд. hamıa- с тем же значением). Потеря носового в башк. mad- 'сбивать масло', батери madhã 'мутовка', вероятнее всего, связана с диссимилятивными процессами, обусловленными наличием в слове начального $m^{14}$. В любом случае, данное фонетическое изменение является поздним, на что указывает сохранение старого $\mathrm{n}$ в генетически наиболее близком к башкарик языке - торвали.

В некоторых восточнодардских языках древнее сочетание *nt(h) отражается в виде одиночного $n$ : вот. dan, башк. d $\Lambda$ n (наряду с $\mathrm{d} \Lambda \mathrm{ndə)}$, торв. $\mathrm{d} \Lambda \mathrm{n}$, май., пхал. dān, шина don 'зуб'; шина man- 'растирать, сбивать пахту'; башк. häman, торв. himān, май. hivān, шина yōnu 'зима'. Есть, однако, основания полагать, что данное фонетическое развитие прошло промежуточную ступень в виде *nd. Отдельные указания на наличие такой ступени имеются почти в каждом из названных здесь языков. Так, в языке башкарик наряду с формой $\mathrm{d} \Lambda \mathrm{n}$ 'зуб' мы находим явно более архаичную форму $\mathrm{d} \Lambda \mathrm{nd} \mathrm{\partial}^{15}$. В пхалура форме ед. ч. dān противостоит форма мн. ч. dānda, что, по-видимому, указывает на наличие в прошлом позиционного перехода $n d>n$, характерного для ауслаута. В одном из диалектов майян - кандия в названии зуба (dədi) обнаруживается озвончение глухого при последующей утрате носового. Поствокальный носовой, однако, должен был сохраняться в

${ }^{11}$ [Zoller 2005: 67].

${ }^{12}$ См. [Online Torwali Dictionary 2011].

${ }_{13}$ В шина согласный $\dot{n}$ является вариантом сочетания $n g$.

${ }_{14}^{14}$ Возможен, в частности, переход поствокального $n$ в назализацию с утратой фонологичности последней в позиции после носового.

15 Архаичность данной формы едва ли может вызывать сомнения, поскольку переход $n>n d$ в башкарик не засвидетельствован. 
более раннем состоянии языка майян, что следует из сопоставления приведенной формы из кандия с формой dān, характерной для ряда других диалектов.

Аналогичная ситуация наблюдается в языке шина. Если в гильгитском диалекте древнему интервокальному *nt(h) соответствует $n$, то в кохистанском мы в подобных случаях обнаруживаем $d$ (ср. гильгит. уōnu, но кохист. yōdu् 'зима' при др.-инд. hemanta-; гильгит. bazōno, но кохист. bazōdu 'весна' при др.-инд. vasanta-; гильгит. man-, но кохист. mod- 'растирать, сбивать пахту' при др.-инд. manthati 'взбалтывает, сбивает масло, трет, растирает', хот.-сак. maṃth- 'сбивать масло'). В том же кохистанском диалекте у ряда существительных с конечным $n$ в форме прямого падежа ед. ч. в остальных формах выступает основа на d: don 'зуб' (прям. пад. ед. ч.) - doda (косв. пад. ед. ч.) - dodi (прям. пад. мн. ч.) - dodo (косв. пад. мн. ч.), pon 'тропинка' (прям. пад. ед. ч.) - podi (косв. пад. ед. ч.) - podi (прям. пад. мн. ч.) - podyo (косв. пад. мн. ч.) ${ }^{16}$. Древние прототипы таких слов содержали кластер *nt(h)17, и противопоставление основ, вероятнее всего, возникло из-за неодинаковой рефлексации более старой консонантной группы в интервокальном и конечном положении. На конце слова она отражалась как $n^{18}$, в то время как между гласными - как $d$. Для более раннего состояния кохистанского диалекта можно с полным основанием реконструировать группу $n d$ в обеих позициях ${ }^{19}$.

Таким образом, хотя современная картина, возможно, несколько затемнена междиалектными заимствованиями, а кроме того, частично неясна вследствие недостатка материала, уже сейчас можно с немалой степенью уверенности предполагать для прашина (т. е. для языка-предка современных диалектов шина) переход $n t>n d$ в интервокальной позиции, а современные рефлексы $n$ и $d$ считать результатами относительно поздних историко-фонетических процессов, затронувших кластер $n d$. Подобная же картина представляется нам наиболее вероятной для кохистанских языков и пхалура, где переход $n d>n$, по всей видимости, являлся позиционным фонетическим изменением, характерным для конечной позиции. В языках торвали и майян на поздний характер этого перехода указывает наличие его в отдельных заимствованиях из пушту (ср. торв. k(h)amān 'хозяин, муж', май. хиvān 'муж' < пушту ха̄wənd 'хозяин, муж'), а также отдельные случаи сосуществования более архаичной формы на -nd и более новой на -n (ср. торв. pand и рап 'дорога' [Grierson 1929: 172]).

Отражение древней группы $n t$, отличное от рассмотренного выше, можно было бы предположить для показателей настоящего времени в языках башкарик и майян (-ă̆nt и -ānt соответственно). Весьма заманчивым кажется сопоставление этих показателей с общеиндоиранским причастием на -ant. Однако некоторые факты заставляют считать данную этимологию сомнительной. В обоих языках формам настоящего времени противо-

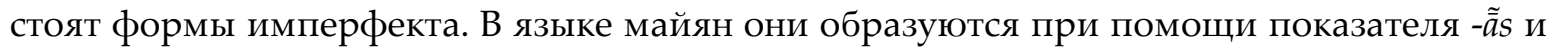
представляют собой исторические стяжения с глаголом-связкой прошедшего времени ãs [Buddruss 1959: 22]. Подобная ситуация характерна и для языка башкарик. Здесь показатель имперфекта имеет вид -а̃̆̌, и конечный элемент -š в нем, вероятнее всего, восхо-

${ }^{16}$ См. [Schmidt, Kohistani 2008].

${ }^{17}$ Ср. др.-инд. panthā, авест. paṇtā'путь, дорога'. Этимологию названия зуба см. выше.

${ }^{18}$ Необходимо иметь в виду, что нулевая флексия в форме прям. пад. ед. ч. в шина возникла в результате отпадения древних окончаний, начинавшихся с гласного. Таким образом, нынешняя конечная позиция восходит к древней интервокальной.

19 Такой же точки зрения придерживаются и авторы грамматики кохистанского диалекта шина, предлагающие реконструировать более ранние формы приведенных выше слов как *dond и *pond [Schmidt, Kohistani 2008: 48]. 
дит к связке прошедшего времени аšūen [Morgenstierne 1940: 221]. Догично предположить, что и презентные формы, подобно имперфектным, могли возникнуть из более ранних стяжений с глаголом-связкой. В настоящем времени последний имеет вид thū (м.p.), thī (ж.p.) в языке башкарик и thū в языке майян. Отпадение конечного гласного словоформы представляется вполне возможным (ср. форму прошедшего времени в башкарик). Утрата придыхания может объясняться тем обстоятельством, что аспирата th оказывалась на конце конечного консонантного кластера ${ }^{21}$ - в позиции, нехарактерной для этой фонемы ни в майян, ни в башкарик. Только в диалекте каньявали языка майян, где форма презенса имеет в исходе краткий гласный, рассматриваемый показатель имеет вид -ã̃thă 22 .

Аналитические формы презенса и имперфекта с глаголом-связкой характерны для целого ряда языков ареала, как дардских (кашмири), так и индоарийских. Во всех этих языках связка сочетается с причастием настоящего времени. Поэтому можно предположить, что элемент $\bar{a} n$ (в башкарик - $\breve{\bar{a}} n)$, к которому присоединяется усеченная связка, является старым суффиксом причастия. Его можно сопоставить с суффиксом причастия

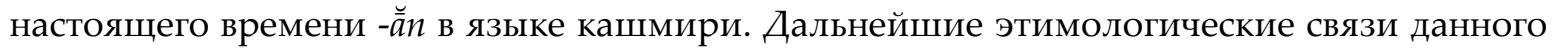
форманта требуют специального исследования.

Из всего сказанного выше можно заключить, что для всех восточнодардских языков, по которым в нашем распоряжении имеется достаточно сведений, есть основание реконструировать рефлекс древней группы *nt в виде $n d$. Остальные рефлексы возникли из более раннего nd вследствие поздних историко-фонетических процессов, а исключения являются, по сути дела, мнимыми.

Большую степень единообразия обнаруживают отражения в восточнодардских языках древних консонантных групп типа «носовой + звонкий». В таких группах обычно происходит утеря второго (неносового) компонента: кашм. lam- 'тащить, тянуть', laman 'волочение, промедление', пхал. lamūm '(я) подвешиваю', май. lam-, торв. l(h)əm- 'подвешивать' при др.-инд. lambate 'висит, свисает; медлит', lambayati 'вешает'; кашм. zām'зевать', zāman 'зевота', шина јӑтіž- 'раззевать рот, зевать', пхал. јāmi 'подбородок’, jāmäi 'зевота', торв. j(h)æmі̄ 'зевота' при др.-инд. јambha- 'зуб, клык; челюсти', jambhayati 'раззевает рот', осет. zæmbyn 'зевать', белудж. zamb 'кусок'; кашм. on, торв. an 'слепой', сави anamuši 'темнота' при др.-инд. andha- 'слепой', andhas-, andhakāra- 'темнота', авест. anda-, хот.-сак. hana- 'слепой'; кашм. tūn, башк. tin, торв. tīn, май. tuin', сави tun̄ī, шина tŭn 'пупок' при др.-инд. tundi- с тем значением; кашм. bon 'куча, стопка', торв. bān 'нитка, шнурок (надеваемый на шею или руку)' [Online Torwali Dictionary 2011], май. bına 'a boundary stone' [Zoller 2005: 301], шина (гильгитский диал.) băn-, (кохистанский диал.) bon- 'надевать' при др.-инд. bandha- 'связь, узы; платина, запруда', bandhati 'связывает', авест. baṇdaiieiti 'связывает', bañda- 'оковы, узы'; кашм. ran-, шина răṇ- 'готовить пищу', башк. rann- 'бить, ударять' при др.-инд. randhayati 'подчиняет; мучает; готовит пищу'). Данное фонетическое развитие, по-видимому, прошло промежуточную стадию в виде носовой геминаты. На это указывают отдельные примеры языка башкарик (ср. выше rann- 'бить, ударять'), а также факт наличия интервокального $m$ в майян, где обычен переход $m>w$.

${ }^{20}$ В XIX в. Дж. Биддалф зафиксировал форму имперфекта с конечным šū: yān šū (“yânshoo”) 'I was coming' [Biddulph 1880: xciii; Morgenstierne 1940: 221].

21 Это относится к наиболее частотной форме настоящего времени - форме м. р. ед. ч., имеющей нулевое окончание. По ней могли впоследствии выровняться и остальные формы.

22 На возможность возникновения формы настоящего времени в каньявали из сочетания с глаголомсвязкой thū указывает Г. Буддрусс [Buddruss 1959: 22]. 
Исключения из данного правила весьма немногочисленны и чаще всего объясняются заимствованием. Так, май. bınd, шина (кохистанский диал.) bandī 'сустав', вероятнее всего, усвоены из персидского (ср. перс. band 'сустав') или же контаминировали с соответствующим персидским словом. Май. sumba(h) 'железный наконечник стрелы или трости, железное зубило’, возможно, как полагает К. Цоллер²3, связано с такими новоиндийскими словами, как хинди sumb(h)ā, неп. sumbā, лахнда (диал. аванкари) summā 'шомпол', пандж. sumbā 'железный молот', синдхи sumbo 'металлический пробойник'. Эти последние, однако, несомненно являются иранизмами (ср. кл.-перс. sumba 'шомпол, бурав, поршень'), и их не следует вслед за Р. Тернером [Turner 1966: 778] возводить к не засвидетельствованной нигде древнеиндийской форме *sumbha-. Отдельные мнимые исключения связаны с ложными этимологиями. Например, кашм. sŏmb(i)r(āw)un 'собирать’, вопреки Р. Тернеру [Turner 1966: 751], необходимо отделять от др.-инд. sambharati 'собирает, готовит'. Этот кашмирский глагол является каузативом от глагола samun 'coбираться', образованным при помощи продуктивного суффикса -(i)r(āw)- [Grierson 1915-32: 912]. Срединный согласный $b$ представляет собой эпентезу, разбившую сочетание $m r$. Эпентеза явно носит факультативный характер, поскольку имеется вариант без нее (somrāwun). Появление эпентетического $b$ обнаруживается в ряде других примеров, в том числе в заимствованиях (ср. tembarhendī 'тамаринд' < кл.-перс. tamr-i hindī 'тамаринд, индийский финик') ${ }^{24}$. Глагол samun в свою очередь, вероятно, восходит к древней основе *samai- (ср. др.-инд. sameti ‘встречается’ $)^{25}$.

Особым образом ведет себя древнее сочетание *-ng- (< общеарийск. *-ng-, *-ngh-). Чаще всего оно сохраняется в неизменном виде или в виде заднеязычного п், являющегося вариантом сочетания ng и не противопоставленного последнему фонологически, в отдельных случаях происходит утрата носового компонента (ср. кашм. ongij, башк. angīr, торв. ängī, май. $\Lambda$ ngūī, пхал. anguri, шина (гильгитский диал.) agui, (кохистанский диал.) hanui 'палец’ при др.-инд. anguli-, anguri-, осет. ængw'yl3, вах. yanglək то же; кашм. zang 'нога (выше щиколотки)', башк. jēnng 'берцовая кость', торв. jān் 'икра ноги',

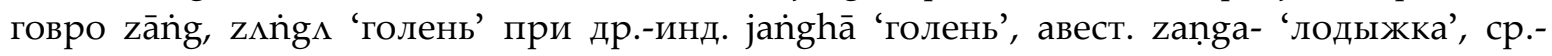
перс. zang 'голень'). Имеются также отдельные примеры перехода *ng > n. Этот переход имел место тогда, когда вследствие отпадения начального гласного сочетание *ng оказывалось в начале слова: кашм. n’oṭh 'большой палец’ при башк. anguç, торв. angūṭh, май. s̀ngō, пхал. anguru, шина aguțo, др.-инд. angușțha- с тем же значением, авест. angušta- 'палец ноги'; кашм., говро, чилиссо nār 'огонь' при башк. ängār, торв. ап்ā, май. ın்ā̄, пхал. angōr, шина agār с тем же значением, др.-инд. añgāra- 'уголь'. Данный переход, вне всякого сомнения, объясняется невозможностью кластера ng (а также его фонетического варианта $\dot{n}$ ) в начальном положении и, следовательно, носит поздний характер. Поздней является и потеря носового в шина, где она затронула лишь часть диалектов (см. выше). Таким образом, сохранение интервокального -ng- следует на определенном (и притом весьма недавнем) историческом этапе предполагать для каждого восточнодардского языка.

Сохранение древнего сочетания *-ng- является для восточнодардских языков общим архаизмом и поэтому не может считаться классифицирующей чертой. Кроме того, оно

\footnotetext{
23 [Zoller 2005: 402] со ссылкой на соответствующую статью словаря Р. Тернера.

24 В кашмири имеются также отдельные примеры появления в заимствованиях неэтимологического $b$ после $m$ в предвокальной позиции: kəmbakh 'помощь' < кл.-перс. kumak с тем же значением; rambi 'стадо' < кл.-перс. rama с тем же значением.

${ }_{25}$ Данную этимологию принимает и Р. Тернер [Turner 1966: 765].
} 
не отличает их от других языков дардской группы (ср. г.-б. anguṛīk, нинг. angū, кал. angūŕyak, кхов. angul, паш. anguṝ 'палец', шум. ãnguṛ-em 'мой палец’; г.-б., нинг., кал., кхов., паш. angār 'огонь'). С отражениями прочих кластеров с начальным носовым ситуация, однако, иная. Насколько позволяет судить доступный языковой материал, их рефлексация во всех языках, не относимых к восточнодардской подгруппе, либо полностью, либо частично отличается от восточнодардской. Так, в языке гавар-бати глухие в позиции после носового не озвончаются (ср. atran 'внутри' при др.-инд. antar- 'внутри', antara- 'внутренний', авест. antarə 'внутри', antara- 'внутренний'; dant 'зуб' при др.-инд. danta-, авест. dantan-; ziāta 'живой' при др.-инд. jīvanta- 'долговечный', jīvant- 'живой'; gēnțh- 'связывать, завязывать' при др.-инд. granthayati ‘связывает, завязывает’; žã̃ $(\lambda<$ *tr) 'водяная мельница' при др.-инд. yantra-; šānkolī 'ветка' при др.-инд. śanku- 'кол, палка'26). Группы типа «носовой + звонкий» при этом сохраняются ${ }^{27}$ (ср. handādup 'темный' при др.-инд. andhas-, andhakāra- 'темнота'; kandik 'плечо' при др.-инд. skandha- с тем же значением). Сохранение глухих в рассматриваемых кластерах предполагатся и для близкородственного шумашти (ср. pо̃̈ 'дорога' при др.-инд. panthā, авест. pantā с тем же значением; zãt 'змея’ при др.-инд. jantu- 'живое существо')28. Наличие столь яркого архаизма в современных кунарских языках дает все основания реконструировать его для общекунарского состояния, пусть даже материал по двум другим языкам кунарской подгруппы (глангали и нингалами) крайне недостаточен.

В языке калаша поведение глухих после носового в предвокальной позиции аналогично восточнодардскому, в конечной позиции второй член старого кластера отпадает (ср. dın (уртсунский диал.), dhındōŕy k (румбурский диал.) 'зуб'; кал. ghrēn, ghrēṇḍ-29 'узел' при др.-инд. grantha- с тем же значением; heman, hemand- 'зима' при др.-инд. hemanta- с тем же значением; phon, phond- 'дорога' при др.-инд. panthā, aвест. paṇtā с тем же значением). Не вполне ясным остается развитие древнего *t в составе группы ${ }^{*} \mathrm{ntr}$. Имеются как примеры озвончения глухого, так и его сохранения: indrə 'внутренности' при др.-инд. āntra- с тем же значением; trun, trond- 'ткацкий станок' при др.-инд. tantra'нить; паутина; ткачество, ткацкий станок'; mandr (уртсунский диал.), mantr (калкатакский диал.) 'слово, язык' при др.-инд. mantra- 'заклинание, молитва; совет'; mãtr-, mātr'говорить' при др.-инд. mantrayate 'говорит; советует'; žontr 'водяная мельница' при др.инд. yantra- 'инструмент, устройство; (ручная) мельница'30. Наиболее вероятным объяснением разнобоя рефлексов нам представляются междиалектные заимствования. Если это объяснение верно, следует предположить сохранение кластера *ntr в неизменном виде в части диалектов калаша, а следовательно, и в пракалаша. Данная историкофонетическая черта четко противопоставляет калаша восточнодардским языкам, где в этом кластере происходит озвончение глухого (примеры см. выше).

\footnotetext{
${ }^{26}$ Примеры см. также [Morgenstierne 1950: 11-12]. Отдельные случаи озвончения после носового (hemand 'зима' при др.-инд. hemanta-, wasand ‘весна' при др.-инд. vasanta-; khēngī 'гребень' при др.-инд. kankata-), вероятнее всего, объясняются заимствованием из соседних восточнодардских языков или калаша (cp. кал. heman(d)- 'зима', кал. bāsund-, пхал. basānd 'весна'; пхал. kēngī 'гребень'). Заимствование должно было иметь место в относительно раннюю эпоху - до перехода * $w>b$ в пхалура и калаша. Следует отметить, что данное объяснение представляется нам единственно правдоподобным при нынешнем уровне знаний: предполагать иноязычное происхождение для примеров с сохранившимися глухими нет оснований ввиду отсутствия среди известных нам соседних языков возможного источника заимствования.

${ }^{27}$ См. также [Morgenstierne 1950: 12].

${ }^{28}$ См. [Morgenstierne 1945 1 : 243].

${ }^{29}$ Варианты с конечным дефисом - основы косвенных падежей.

${ }^{30}$ Об отражении групп *nt и *ntr в калаша см. также [Morgenstierne 1973: 199].
} 
Ассимиляция звонкого в позиции после носового перед гласным для калаша, повидимому, нехарактерна: učhund- 'спускаться' < *awaśčand- 'спрыгивать' [Turner 1966: 38], ср. др.-инд. skandati 'прыгает'; brundik 'разжевывать, скрипеть зубами' [Trail, Cooper 1999: 51] < *wirand-, ср. др.-инд. radati 'роет; царапает; грызет, гложет', ср.-перс. randītan 'строгать', кхов. rondik 'царапать'; pinḍ 'деревянный мячик' [Trail, Cooper 1999: 245], ср. др.-инд. piṇda- 'ком, кусок', пали piṇda- ‘ком, шарик', арм. pind 'крепкий, сжатый’ (< иран.). Единственным примером, в котором можно предположить подобный историкофонетический процесс, является b(h)onik 'связывать, завязывать'. Однако, как указывает Г. Моргенстьерне [Morgenstierne 1973: 199], в калаша могла отразиться древняя презент-

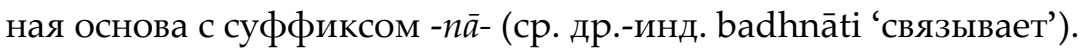

В языке пашаи рефлексы глухих и звонких согласных в позиции после носовых совпадают [Morgenstierne 1967: 36]. Обе серии отражаются как звонкие, т. е. имеет место озвончение глухих и сохрание звонких: sabaj- 'делать, строить' $(b<m b)$ при др.-инд. sampadyate 'сделан, произведен'; gambā 'глубокий' при др.-инд. gambhan- 'глубина'; dānd 'зуб' при др.-инд. danta-, авест. dantan- с тем же значением; mand- 'сбивать масло' при др.-инд. manthati 'взбалтывает, сбивает масло, трет, растирает’, хот.-сак. mamth'сбивать масло'; pand 'дорога' при др.-инд. panthā, авест. paṇtā с тем же значением; andā 'слепой' др.-инд. andha-, авест. anda-, хот.-сак. hana- с тем же значением; ха̄nd 'плечо' при др.-инд. skandha- с тем же значением; wənd- 'находить' при др.-инд. vindati 'находит, обладает’, авест. vindonnti ‘(они) находят’31. Данная рефлексация сходна с восточнодардской лишь частично, а именно в том, что касается глухих. Сохранение звонких в группах с начальным носовым является ярким отличием пашаи от восточнодардских языков.

В языке кховар в конце слова ${ }^{32}$ отражение консонантных групп с начальным носовым аналогично таковому в кохистанских языках и пхалура: эти группы теряют второй компонент (ср. don 'зуб' при др.-инд. danta-, авест. dantan- с тем же значением; уomun 'зима' при др.-инд. hemanta- с тем же значением; pon 'дорога' при др.-инд. panthā, aвест. pantā с тем же значением; kan 'дерево' < *skānda-, cp. др.-инд. skandha- 'ствол дерева', skandhas'крона дерева'з3; dim 'тело, ствол дерева; живот' при др.-инд. dimba- 'тело’). В интервокальном положении рассматриваемые кластеры ведут себя так же, как в языке пашаи, т. е. глухие согласные озвончаются, а звонкие сохраняются без изменения (ср. andren 'внутри' при др.-инд. antar- 'внутри', antara- 'внутренний', авест. antarə 'внутри', antara- 'внутренний'; kandu 'дикий миндаль' при др.-инд. kāntā (название различных растений), вайгали kãta 'миндаль'; tandeni 'нитка в прялке' при др.-инд. tanti-, tantu- 'нить'; мmbēr 'часть дверной рамы' при др.-инд. umbara- 'верхняя дощечка дверной рамы'; rondik 'царапать, отчищать' < *rand-, ср. др.-инд. radati 'роет; царапает; грызет, гложет', ср.-перс. randītan 'строгать'; randezu 'жареное мясо’ при др.-инд. randhayati ‘готовит пищу'). Предполагаемые исследователями отдельные возможные примеры утраты зубного после носового в интервокальном положении представляются нам спорными и могут иметь иное объяснение. Так, глаголы ušpunik 'плясать; взбрыкивать (о лошади)' и ušpuneik 'заставлять прыгать', повидимому, следует сравнивать с др.-инд. phāṇāyati 'заставляет прыгать' (< *sphāṇāyati?) ${ }^{34}$,

${ }^{31}$ Примеры см. также [Morgenstierne 1967: 36-37].

32 Имеется в виду новый ауслаут, возникших в результате падения древнего флективного показателя.

${ }_{33}$ Данная этимология представляется нам семантически более вероятной, чем предлагаемое Г. Моргенстьерне и Р. Тернером [Morgenstierne 19732; Turner 1966: 154] сопоставление с др.-инд. kāṇạa- 'узел растения; стрела'.

${ }^{34}$ Вероятнее всего, кховарские глаголы восходят к производному с превербом *ud-. Ср. также глагол phonik 'танцевать', возводимый Р. Тернером к тому же корню phan- [Turner 1966: 508]. 
а не с др.-инд. spandati 'вздрагивает, трепещет', как это делает Р. Тернер [Turner 1966: 89]. Глагол manik 'тереть, шлифовать; штукатурить' может быть сопоставлен с др.-инд. mrrdnāti 'трет, растирает, дробит, толчет', и его, таким образом, не обязательно вслед за Р. Тернером [Tuner 1966: 565] возвоздить к общеиндоиранскому корню *manth- 'сбивать масло, тереть'.

Все рассмотренные выше факты позволяют отражение древних консонантных кластеров с начальным носовым считать изоглоссой, объединяющей все восточнодардские языки и (за исключением отражений сочетаний типа «носовой + заднеязычный») противопоставляющей их всем прочим языкам дардской группы ${ }^{35}$. Таким образом, она может рассматриваться как еще одна классифицирующая характеристика предполагаемой восточнодардской подгруппы.

Еще одна возможная общевосточнодардская черта упоминалась нами в прошлых работах ${ }^{36}$. Речь идет о рефлексации ряда праиндевропейских консонантных групп с начальными гуттуральными. В частности, утверждалось, что кластеры *ks, *k’s и k’p отражаются в восточнодардских языках единообразно, а именно в виде церебрального с̣̆ или его более поздних рефлексов, в то время как в остальных языках дардской группы отражения сочетаний с начальным палатовелярным и простым велярным различны: первые переходят в палатальную аффрикату čh, вторые - в церебральную аффрикату с̆h, непосредственным прототипом которой, возможно, было сочетание *ks [Коган 2000; 2005 : 75-94]. В настоящее время, однако, данная точка зрения нуждается если не в пересмотре, то, по крайней мере, в уточнении. Детальный анализ материала, в том числе нового, показывает, что восточнодардская рефлексация кластеров с и.-е. начальным *k' вовсе не является единообразной (ср. кашм. с̌h- глагол-связка, пхал. ç̌hītru, шина с̣̌eç 'поле' при др.-инд. kșeti 'пребывает, проживает', kșetra- 'поле, земля, местность', авест. šaе̄iti 'проживает', šōiӨra- 'округ' < и.-е. * k’pei- [Pokorny 1959: 626]; шина (гильгитский диал.), сави

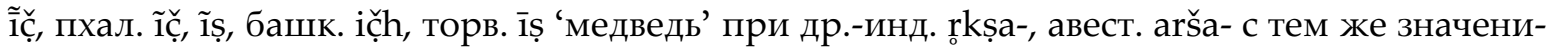
ем < и.-е. *rok’po- [Pokorny 1959: 875]; башк. kačāl, торв. kašāl, сави kačalțōpa, говро, кашм. kach 'подмышка', торв. kас̌, kæš, май. $k a c h(\bar{e})$, kas, сави kēč(i), шина kас̌i 'около, близко, рядом' при др.-инд. kakșa-, авест. kaša- 'подмышка'< и.-е. *kok'sā- [Pokorny 1959: 611] ${ }^{37}$; кашм. kəčh 'нижняя часть груди, где качают детей', май. kuiç̌hi 'бок' при др.-инд. kukși'(беременная) утроба, живот, брюхо', kukșī (дв.ч.) 'щеки, ягодицы', др.-ир. *kuši- 'сторона, сторона тела, часть тела' (> согд. qwš-, qwšy- 'сторона, бок’) < и.-e. *kuk'-s- [ЭСИЯ 4: 411-412]; кашм. tačh- 'срезать, скрести', tōrach 'стамеска'38, башк. teç̌h, шина taç̌i 'струг', торв. taṣ- 'срубать', tæṣ 'топор', tāṣ 'кирка; срубание', май. taç̌h- 'вырезать, плотничать', tas kar- 'срезать стружку (с куска дерева специальным топором)', пхал. taç-, шина thač'рубить, тесать, обтесывать', при др.-инд. takșati, авест. tašaiti ‘обтесывает, плотничает' <

${ }^{35}$ Неясной остается лишь ситуация с языком тирахи. Отражения в нем рассмотренных выше групп согласных не могут быть детально проанализированы вследствие крайнего недостатка материала.

${ }^{36}$ См., например, [Коган 2000; 2005].

37 Развитие у производных древнего обозначения подмышки семантики 'близко, рядом' наблюдается также в отдельных индоарийских (неп. kahã < kakșa- [Turner 1966: 128]) и нуристанских (вайг. kačã̃t [ibid.]) языках. Ср. также послелог kșe ‘в’ в языке пушту, восходящий к форме локатива того же слова - *kašai [NEVP: 41].

38 По-видимому, из более раннего *tach. Срединное сочетание ōr возникло, вероятно, под влиянием tūr ‘струг, топорик' (< *tōrī, cp. форму косв. пад. ед.ч. tōri). Ср. пример появления неэтимологического сочетания ar в продолжении того же глагольного корня в персидском (tarāšīdan 'тесать, стругать, вырезать'), объясняемое контаминацией с семантически близким глаголом хarāšīdan 'скрести, царапать' [Сheung 2007: 389]. 
и.-е. *tek'p- [Pokorny 1959: 1058-1059]; кашм. dačhyun, май. daç̌hō, шина daçhinu 'правый', башк. lāç̌him, пхал. deç̌hini 'правая рука', при др.-инд. dakṣiṇa-, авест. dašina- 'правый’ < и.-е. *dek's-i-no- [Mayrhofer 1992: 690-691]; кашм. mach 'плечо, рука выше локтя’ при авест. аša- 'плечо', др.-инд. akșa- 'ось'39 < и.-е. *ak's- (образование от корня *ag'- 'вести' [Pokorny 1959: 4-7]); кашм. mach 'утешение, мягкое убеждение, умиротворение' при др.-инд. mrakșati ‘гладит, мажет’, mrakșaṇa- 'масло', где kṣ < и.-е. *k's < *g’s40).

Приведенные здесь рефлексы могут быть возведены к двум прототипам. Кашм. с̌h, а также фонемы ç̣h, с̣̆ и ș в остальных восточнодардских языках представляют собой закономерные продолжения старой церебральной аффрикаты с̣̆h, в то время как кашм., май., говро ch, май. s, торв. ц̌, башк., торв., сави, шина с̌ отражают более раннюю палатальную аффрикату с̌h. Поскольку рефлексы обоих прототипов могут встречаться в производных одного корня ${ }^{41}$, явный разнобой в звукосоответствиях должен объясняться одной из двух причин: заимствованием из родственных языков или позиционными историко-фонетическими процессами ${ }^{42}$. Первое объяснение представляется теоретически возможным лишь для части примеров. Так, кашм. kach 'подмышка' могло бы быть усвоено из некоторого индоарийского языка, где соответствующее слово имело палатальную аффрикату (ср. пандж., лахнда kассh 'подмышка'). Речь в этом случае должна идти о раннем заимствовании, проникшем в кашмири до дентализации старых аффрикат палатального ряда. Однако данная гипотеза маловероятна для этимологически родственных примеров из других восточнодардских языков, в том числе из не подвергавшегося значительному индоарийскому влиянию языка шина ${ }^{43}$. В этом последнем, в свою очередь, внешним влиянием может объясняться палатальная аффриката в глаголе thас̌'рубить, тесать, обтесывать'. Источником заимствования в данном случае мог являться соседний с шина язык кховар (ср. кхов. tос̌һ- 'рубить'). В то же время заимствование из кховар по лингвогеографическим причинам представляется невероятным для май. tas 'срезание стружки', также обнаруживающего рефлекс палатального. Для данного слова внешний источник не просматривается, и сомнения в его исконности безосновательны.

Позиционное распределение церебральной и палатальной аффрикат и их рефлексов представляется неочевидным. В начале слова отмечены только продолжения более раннего церебрального ب̣̆ $h^{44}$. В интервокальном положении встречаются обе аффрикаты и их более поздние отражения. При этом, однако, обращает на себя внимание тот факт, что среди примеров интервокальной палатальной аффрикаты (и ее продолжений) совершенно отсутствуют несомненные древние образования. Так, суффиксальный элемент āl в башк. kačāl, торв. kašāl и элемент al в сави kačalțōpa 'подмышка' не обнаруживают никаких этимологических связей в древних арийских языках, что позволяет считать их поздними наращениями. Краткий $i$ в шина представляет собой суффикс, часто встре-

\footnotetext{
${ }^{39}$ Начальный m, вероятно, по аналогии с moț 'плечи, закорки'.

40 Данный корень исторически представляет собой суффиксальное образование (вероятнее всего, остаток вышедшего из употребления s-презенса) корня тrj- 'тереть' < и.-е. *melg'- [Mayrhofer 1963: 668, 670671]. Характерное для кашмири семантическое развитие находит типологическую параллель, например, в русском языке (ср. умасливать, подмазывать).

${ }^{41}$ Ср., например, приведенные выше различные образования от индоевропейского корня *tek'p-.

42 Следует также иметь в виду возможность отдельных случаев изменения по аналогии.

43 Примечательно, что в шина данная основа утратила значение части тела и употребляется исключительно в значении 'около, близко, рядом'. Такая семантическая трансформация, разумеется, могла произойти с индоарийским заимствованием, но только в том случае, если оно было усвоено достаточно давно, что для языка шина маловероятно.

${ }^{44}$ Ср. первые три примера из приведенного выше списка.
} 
чающийся в наречиях места (ср. āni 'здесь', āli 'там', kōni 'где?', khiri 'внизу'), и современная форма kас̌i 'около, близко, рядом’ может, таким образом, являться производной от более раннего *kač, образованной в сравнительно недавнее время по аналогии с рядом семантически близких слов. В языке сави форма kе̄с̌i 'около, рядом', по всей видимости, является формой локатива от *kас̌, образованной по продуктивной модели при помощи суффикса $\breve{1}^{45}$. Синхронной формой локатива является и май. kachē. С другой стороны, в тех случаях, когда интервокальная позиция, несомненно, является старой, мы обнаруживаем церебральную аффрикату или ее рефлекс (ср. кашм. dačhyun, май. daç̌hō, шина daç̌hiṇu 'правый', башк. lāç̌him, пхал. deç̌hini 'правая рука', при др.-инд. dakșina-, авест. dašina- 'правый'; ср. также приводившиеся выше глагольные основы, восходящие к и.-е. *tek'p-, последний согласный в которых почти всегда предшествует форманту, начинающемуся с гласного $\left.{ }^{46}\right)$.

Таким образом, для любого восточнодардского языка можно постулировать более раннее состояние, в котором палатальная аффриката могла встречаться только в позиции конца слова. Для некоторых языков (в частности, для кашмири) такая ситуация характерна и на синхронном уровне. Вместе с тем в конечной позиции, как и в интервокальной, наблюдается разнобой рефлексов, требующий объяснения. Отчасти он связан с позиционными фонетическими изменениями, приведшими к церебрализации более ранней палатальной аффрикаты. Именно так, по всей видимости, следует объяснять появление конечных церебральных в названиях медведя (шина - гильгитский диал., сави


ном случае могла быть вызвана соседством со слоговым го, фонетически представлявшим собой сочетание типа «гласный $+\mathrm{r}$ \} ^ { 4 7 } \text { . В отдельных случаях появление церебрального, } возможно, было связано с изменениями по аналогии. Так, конечный церебральный сибилянт в торв. tæș 'топор' и tāș 'кирка; срубание', возможно, возник под влиянием форм глагола taș- 'срубать'.

Один из приведенных выше примеров заслуживает особого рассмотрения. Это кашм. kəс̌h 'нижняя часть груди, где качают детей' при др.-инд. kukși- '(беременная) утроба, живот, брюхо', kukșī (дв. ч.) 'щеки, ягодицы', др.-ир. *kuši- 'сторона, сторона тела, часть тела'. Конечный с̌ в кашмирском слове регулярно продолжает более старый церебральный с̣. Причина появления в этом слове рефлекса церебрального, а не палатального на первый взгляд неясна. Ясно лишь то, что она едва ли может заключаться в какихто позиционных историко-фонетических процессах, поскольку в других словах в аналогичной позиции мы обнаруживаем отражение палатальной аффрикаты (ср., напр., kach 'подмышка').

Найти приемлемое объяснение, возможно, поможет привлечение внешних данных. Кашмирское слово имеет этимологическое соответствие в языке майян (kuiç̌hi ‘бок’), в котором церебральная аффриката находится не в конечном, а интервокальном положении. Оба существительных (кашмирское и майян) относятся к женскому роду, из чего, в частности, следует, что конечный краткий $i$ в майян продолжает долгий $\bar{\imath}-$ обычное окончание имен женского рода в дардских языках. В кашмири это окончание пало, однако его падение, по всей видимости, следует датировать относительно недавней эпо-

45 Подробнее об этом суффиксе см. [Buddruss 1967: 33-34].

46 Большая часть этих формантов унаследована от общеарийского (а часто и от праиндоевропейского) языкового состояния.

47 В позиции после слогового г в дардских языках часто происходила и церебрализация зубных смычных. Подробнее см. [Коган 2005: 22-26]. 
хой. В работе [Коган 2009] мы показали, что данный процесс завершился (исчезновением конечного краткого $i$, развившегося из более раннего долгого $\bar{\imath}$ ) уже после развития умлаута, а следовательно, заметно позже начала усвоения языком кашмири персидских и арабских заимствований. Таким образом, можно говорить о новом кашмирском ауслауте, где индоевропейские сочетания *k's и *k'p отражаются так же, как в интервокальной позиции. Такой же новый ауслаут следует предполагать и для башк. teç̆ 'струг', где гласный $е$ явно развился из более раннего $a$ в позиции і-умлаута и, таким образом, указывает на наличие в прошлом конечного $\bar{i}^{48}$.

Переход этимологических соответствий др.-инд. kukși- в женский род в части дардских языков ${ }^{49}$ может объясняться тем фактом, что в древности это слово весьма часто выступало в форме двойственного числа с окончанием -i 50 , впоследствии воспринятое как окончание женского рода. По всей видимости, аналогичный процесс затронул также название глаза. Данное общеарийское слово, относившееся в древности, вероятнее всего, к среднему роду (ср. др.-инд. akși-, авест. аš- c.p.) имеет во многих дардских языках продолжения женского рода. При этом все восточнодардские обозначения глаза обнаруживают конечный долгий $\bar{\imath}$ или его следы (в частности, в виде і-умлаута): торв. așī (ж.p.),

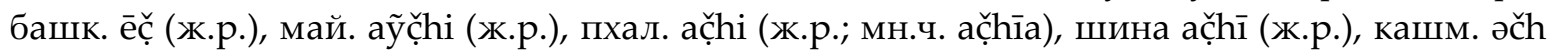
(ж.р.). Этот долгий $\bar{\imath}$ исторически может (как и в случае с соответствиями др.-инд. kukși-) представлять собой переосмысленный показатель двойственного числа ${ }^{51}$.

Праиндоевропейский прототип арийских названий глаза реконструируется как * $\mathrm{ok}^{\mathrm{w}}(\mathrm{e}) \mathrm{s}-$ или * $\mathrm{ok}^{\mathrm{w}} \mathrm{p}$ - [Pokorny 1959: 775-777], однако его продолжения в нуристанских, части дардских языков, а также в языке Авесты ясно указывают на праформу с палатальным k' (*ok's- или *ok'p-). В наших прошлых работах [Коган 2000; 2005: 92-93] мы показали, что данная нерегулярность, вероятнее всего, объясняется имевшей место еще в об-

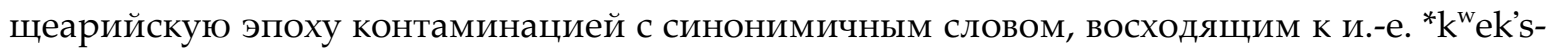
(cp. др.-инд. cakșus-, авест. с̌ašman- 'глаз'). Из этого следует, что приведенные здесь восточнодардские формы могут с полным основанием рассматриваться вместе с примерами отражения индоевропейских групп с начальным палатальным (вернее, их общеарийских рефлексов) в виде церебральной аффрикаты в интервокальном положении.

Суммируя вышесказанное, мы можем констатировать, что восточнодардское отражение праиндоевропейских сочетаний *k’s и *k’p в виде церебральной аффрикаты ç̣h или ее более поздних продолжений характерно для всех позиций в слове, кроме конечной, где следует предполагать палатальный рефлекс. Данная рефлексация прослеживается во всех языках, традиционно относимых к восточнодардским, и при этом противопоставляет их дардским языкам прочих ветвей. Таким образом, она может быть признана общевосточнодардской классифицирующей характеристикой. Относительно характера рассмотренных выше историко-фонетических процессов представляется необходи-

48 Данной точки зрения придерживается Р. А. Тернер, предполагающий для слова башкарик праформy *takșī [Turner 1966: 319]. Интересно, что в приведенном нами списке примеров данному слову противостоят слова кашмири и майян (tōrach и tas соответственно), восходящие, скорее всего, к основам на краткий $a$ (вероятно, к именам действия, ср. др.-инд. имя деятеля takșa- 'плотник'). Кашмирское слово относится к женскому роду, однако отсутствие в нем следов $i$-умлаута не позволяет возвести его к древней основе на долгий $\bar{\imath}$. По-видимому, в женский род оно перешло под влиянием других слов с исходом на ch (cр. расh, ж.р., 'вера, доверие', tach, ж.р., 'пустяк', təch, ж.р., 'сила', уесh 'желание’ и мн. др.).

${ }^{49} \mathrm{~B}$ древнеиндийском данное слово относится к мужскому роду.

50 Такая ситуация зафиксирована в древнеиндийском.

51 Показательно, что в языке Авесты данное слово засвидетельствовано только в форме двойственного числа (аธ̌ī). 
мым сделать некоторые дополнительные пояснения. Все встреченные нами примеры с отражением и.-е. *k’s и *k’p в виде палатальной аффрикаты или ее рефлексов относятся или восходят к именным частям речи. Имена с исходом на согласный в современных восточнодардских языках, как правило, восходят к древним формам номинатива, образованных от основ с исходом на краткий гласный. Иными словами, современная конечная позиция возникла из древней интервокальной. Единственная особенность этой старой интервокальной позиции состояла в том, что второй гласный всегда был кратким и относился к последнему слогу. При нынешнем уровне знаний мы не можем с уверенностью утверждать, что утрата древних номинативных показателей была свершившимся фактом в общевосточнодардскую эпоху. Поэтому более осторожно выведенное нами выше правило можно было бы сформулировать так: праиндоевропейские сочетания *k’s и *k’p отражаются в восточнодардских языках в виде палатального с̌h и его более поздних продолжений в древней интервокальной позиции перед последним кратким гласным в слове.

Необходимо иметь в виду, что данное правило относится только к рефлексам индоевропейских консонантных групп с начальным палатовелярным. Сочетание * ${ }^{*}$ s во всех позициях отражается единообразно - в виде с̣̆h или его более поздних рефлексов (ср. кашм. čhir 'овечье или козье молоко', башк., пхал. ç̣̂̄r, сави ç̌hir, торв. ç̣ī ‘молоко', шина ç̌îri 'вымя' при др.-инд. kṣīra- 'молоко', kșīrin- 'дающий молоко', общеиран. *xšīra- 'молоко’ > осет. æxsyr, мундж. xšīro с тем же значением ${ }^{52}$; шина phaç̌īli 'крыло, перо’, май. pāç̌h, говро pāșe 'перо', кашм. (диал. каштавари) рас̌han, сави phēçina, башк. paç̌hin, торв. peșin 'птица' при др.-инд. pakșa- 'перо, крыло, бок', pakșin- 'крылатый; птица', осет. faxs ‘бок' < и.-е. *pok-s- [Pokorny 1959: 792]; кашм. mәс̌h, майян тау̃̌çhī, шина (гильгитский диал.) mașī, 'муха', пхал. maç̌urī, башк. māç̌ēr 'пчела', пхал. mēçhī, шина maç̌hī, кашм. mãč 'мед’ при др.-инд. makșā 'муха, пчела', mākșika- 'пчелиный; мед’, авест. maхši- 'муха' < и.-е. *mak-s- [Pokorny 1959: 699]; кашм. račh-, май. raç̌h- ‘защищать', шина (гильгитский диал.) raç̌- 'беречь, наблюдать, караулить' при др.-инд. rakșati 'охраняет' < и.-е. *aleks-53; кашм. уӗс̌h 'домовой, сверхъестественное существо', шина уас̆ 'демон’ при др.инд. yakșa- 'явление, предзнаменование; призрак, якша (вид сверхъестественных существ)', yakṣ- 'являться, показываться, обнаруживаться', общеиран. *уахธ̌- > ягн. уахธ̌‘виднеться'54; кашм. wačh 'грудь' при др.-инд. vakșas- то же, осет. wæxsk 'плечо' < *wek-s[Абаев 1989: 100-101]).

Рефлекс и.-е. *k’s и *k'p может быть с полным основанием реконструирован для общедардского праязыкового состояния в виде палатального č $h^{55}$. Поэтому причиной наличия у данных сочетаний двух общевосточнодардских рефлексов (церебрального и палатального) следует считать церебрализацию более старой палатальной аффрикаты в ряде позиций. Правило распределения этих рефлексов в окончательной формулировке будет, таким образом, выглядеть следующим образом: общедардская палатальная аффриката с̌h, в общевосточнодардском праязыковом состоянии переходит в цееребральную аффрикаmу с̣̆h везде, кроме древней интервокальной позиции перед последним кратким гласным в слове.

52 Соответствие др.-инд. kṣ общеиран. хธ̌ четко указывает на праиндоевропейский прототип с начальным велярным.

53 М.Майрхофер предлагает для данного слова реконструкцию с начальным вторым ларингалом ${ }^{*} \mathrm{~h}_{2}$ leks- [Mayrhofer 1996: 422].

${ }^{54}$ Соответствие др.-инд. kṣ общеиран. хš четко указывает на праиндоевропейский прототип с начальным велярным.

55 Отражения этих сочетаний в дардских языках, не относящихся к восточнодардским, подробно рассматриваются в нашей монографии [Коган 2005: 75-94]. 
Мы рассмотрели три изоглоссы, объединяющие практически все языки, традиционно относимые к восточнодардской подгруппе ${ }^{56}$ и при этом противопоставляющие их остальным дардским языкам. К этим изоглоссам следует добавить упомянутый в начале данной статьи и подробно проанализированный в работе [Васильев, Коган 2013] переход *st > (t)th в интервокальном положении. Сам факт наличия общих инноваций, объединенных в пучок, заставляет нас признать существование восточнодардской генетической общности весьма вероятным. Представляется, однако, небезынтересным остановиться на еще одном вопросе: не могло ли появление общих восточнодардских изоглосс быть следствием языковых контактов, в частности, контактов с индоарийскими языками ${ }^{57}$ ? Для ответа на этот вопрос необходимо представлять себе общую картину распространения данных изоглосс в ареалах, географически близких к восточнодардскому. Эта картина хорошо описывается при помощи следующей таблицы:

Табл. 1.

\begin{tabular}{|c|c|c|c|c|c|c|c|}
\hline \multirow{2}{*}{$\begin{array}{l}\text { Историко-фонетическая } \\
\text { изоглосса }\end{array}$} & \multicolumn{4}{|c|}{$\begin{array}{l}\text { Распространение в дардских языках, } \\
\text { не относящихся к восточнодардским }\end{array}$} & \multicolumn{3}{|c|}{$\begin{array}{l}\text { Распространение в арийских } \\
\text { языках прочих подгрупп }\end{array}$} \\
\hline & $\begin{array}{l}\text { кунар- } \\
\text { ские }\end{array}$ & пашаи & кховар & калаша & $\begin{array}{c}\text { индо- } \\
\text { арийск. }\end{array}$ & иранск. & $\begin{array}{l}\text { нури- } \\
\text { станск. }\end{array}$ \\
\hline$*_{-s t}->-(\mathrm{t}) \mathrm{th}(-)$ & - & - & - & - & + & - & - \\
\hline *śr > ș (во всех позициях) & - & - & - & - & - & + & - \\
\hline${ }^{*}-\mathrm{NT}->-\mathrm{ND}(-),{ }^{*}-\mathrm{ND}->-\mathrm{NN}(-)$ & - & - & - & - & + & + & - \\
\hline $\begin{array}{l}\text { *čh-, -čh- >*-ç̌- } \\
\text { (кроме позиции перед послед- } \\
\text { ним кратким гласным в слове) }\end{array}$ & - & - & - & - & - & - & - \\
\hline
\end{tabular}

Как можно видеть из таблицы, ни один язык, не относящийся к восточнодардским, не разделяет всего пучка выделенных нами изоглосс. Более того, большая часть привлекавшихся для сравнения языков не затронута ни одной из них. Исключение составляют лишь индоарийские и иранские языки, но и в них отмечены лишь две из четырех рассмотренных выше черт. Таким образом, можно констатировать, что эти черты в целом мало распространены за пределами восточнодардской подгруппы. Наличие же историко-фонетического перехода, характерного исключительно для восточнодардских языков (церебрализация палатального с̌h), и вовсе исключает возможность того, что весь восточнодардский пучок инноваций возник вследствие внешнего влияния.

\section{Сокращения}

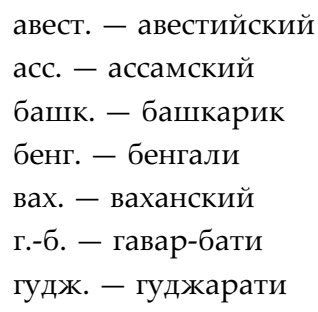

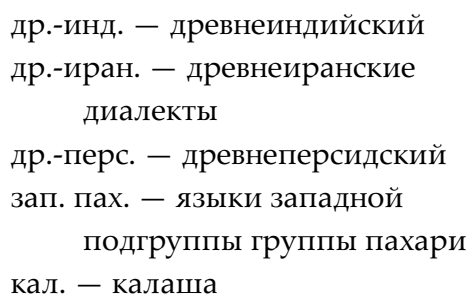

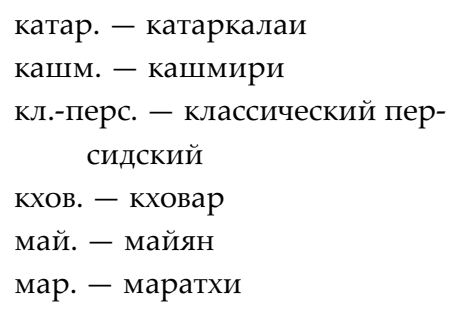

56 Некоторая степень неопределенности может оставаться для малоизученных языков, для которых известен лишь небольшой объем лексики, например для катаркалаи или чилиссо.

${ }^{57}$ О благоприятных условиях для таких контактов см. [Васильев, Коган 2013]. 


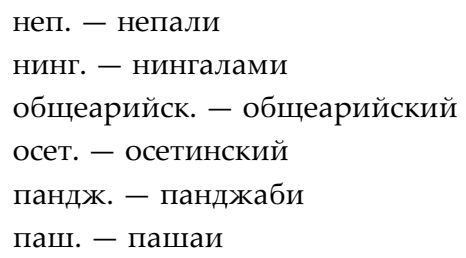

\author{
пракр. - пракриты \\ пхал. - пхалура \\ синг.-сингальский \\ согд. - согдийский \\ ср.-перс.-среднеперсидский \\ тир. - тирахи
}

\author{
торв. - торвали \\ хот.-сак. - хотаносакский \\ цыг. - цыганский \\ шум. - шумашти
}

\section{Питература}

Абаев, 1989 - Абаев В. И. Историко-этимологический словарь осетинского языка. Том IV. А.: Наука, Ленинградское отделение, 1989. [Abaev V. I. Istoriko-etimologicheskij slovar' osetinskogo yazyka. Tom IV. L.: Nauka, Leningradskoe otdelenie, 1989.]

Васильев, Коган 2013 - Васильев М. Е., Коган А. И. К вопросу о восточнодардской языковой общности // Вопросы языкового родства, №10 (2013). С. 149-177. [Vasil'ev M. E., Kogan A. I. K voprosu o vostochnodardskoj yazykovoj obschnosti // Voprosy yazykovogo rodstva, №10 (2013). S. 149-177.]

Коган 2000 - Коган А. И. О рефлексации некоторых индоевропейских консонантных групп с начальными гуттуральными в дардских языках // Проблемы изучения дальнего родства языков на рубеже третьего тысячелетия. Доклады и тезисы международной конференции. М.: РГГУ, 2000. С. 65-88. [Kogan A. I. O refleksatsii nekotorykh indoevropejskikh konsonantnykh grupp s nachal'nymi guttural'nymi $\mathrm{v}$ dardskikh yazykakh // Problemy izucheniya dal'nego rodstva yazykov na rubezhe tret'ego tysyacheletiya. M., 2000. S. 65-88.]

Коган 2005 - Коган А. И. Дардские языки. Генетическая характеристика. М.: Восточная литература, 2005. [Kogan A. I. Dardskie yazyki. Geneticheskaya kharakteristika. M.: Vostochnaya literatura, 2005.]

Коган 2009 - Коган А. И. К вопросу о ряде фонетических изменений в языке кашмири и их относительной датировке // Аспекты компаративистики IV. М.: РГГУ, 2009. С. 25-54. [Kogan A. I. K voprosu o ryade foneticheskikh izmenenij v yazyke kashmiri i ikh otnositel'noj datirovke // Aspekty komparativistiki IV. M.: RGGU, 2009. S. 25-54.]

Эдельман 1992 - Эдельман Д. И. Еще раз об этапах филиации арийской языковой общности // Вопросы языкознания, № 3, 1992. [Edel'man D. I. Esche raz ob etapakh filiatsii arijskoj yazykovoj obschnosti // Voprosy yazykoznaniya, № 3, 1992.]

ЭСИЯ 4 - Эдельман Д. И. Этимологический словарь иранских языков. Том 4: i-k. М.: Восточная литература PAH, 2011. [Edel'man D. I. Etimologicheskij slovar' iranskikh yazykov. Tom 4: $i-k$. M.: Vostochnaya literatura RAN, 2011.]

Biddulph 1880 - Tribes of the Hindoo Koosh by Major J. Biddulph, B.S.C., Political Officer at Gilgit. Calcutta: Office of the Superintendent of Government Printing, 1880.

Buddruss 1959 - Buddruss G. Kanyawali. Proben eines Maiyã-Dialektes aus Tangir (Hindukusch). München, 1959.

Buddruss 1960 - Buddruss G. Die Sprache von Wotapur und Katarqala. Bonn, 1960.

Buddruss 1967 - Buddruss G. Die Sprache von Sau in Ostafghanistan (Beiträge zur Kenntnis des Dardischen Phalura). München, 1967.

Buddruss 1977 - Buddruss G. Nochmals zur Stellung der Nuristan-Sprachen des afghanischen Hindukusch // Münchener Studien zur Sprachwissenschaft. H. 36. München, 1977.

Edelman 1983 - Edelman D. I. The Dardic and Nuristani languages. M., 1983.

Cheung 2007 - Cheung J. Etymological Dictionary of the Iranian Verb. Leiden - Boston: Brill, 2007.

Grierson 1919 - Grierson G. A. Linguistic Survey of India. Vol. VIII, pt. 2. Specimens of the Dardic or Piśāca Languages (including Kāshmīrì). Calcutta, 1919.

Grierson 1929 - Grierson G. A. Torwali, an Account of a Dardic Language of the Swat Kohistan. L., 1929.

Grierson, 1915-32 - Grierson G. A. A Dictionary of the Kashmiri Language. Vol. I-IV (Bibliotheca Indica. Work No. 229) Calcutta: Royal Asiatic Society of Bengal, 1915-32.

Mayrhofer 1963 - Mayrhofer M. Kurtzgefasstes etymologisches Wörterbuch des Altindischen. Heidelberg: Carl Winter Universitätsverlag, 1963.

Mayrhofer 1992 - Mayrhofer M. Etymologisches Wörterbuch des Altindoarischen. I Band. Heidelberg: Carl Winter Universitätsverlag, 1992. 
Mayrhofer 1996 - Mayrhofer M. Etymologisches Wörterbuch des Altindoarischen. II Band. Heidelberg: Universitätsverlag Carl Winter, 1996.

Morgenstierne 1926 - Morgenstierne G. Report on a Linguistic Mission to Afghanistan. Oslo, 1926.

Morgenstierne 1932 - Morgenstierne G. Report on a Linguistic Mission to North-Western India. Oslo, 1932.

Morgenstierne 1940 - Morgenstierne G. Notes on Bashkarik // Acta Orientalia, vol. XVIII, pt. 3 - 4. Leiden, 1940. P. 206-257.

Morgenstierne $1945_{1}$ - Morgenstierne G. Notes on Shumashti, a Dardic Dialect of the Gawar-Bati Type // Norsk Tidsskrift for Sprogvidenskap. Bd. XIII. Oslo, 1945.

Morgenstierne $1945_{2}$ - Morgenstierne G. Indo-European k' in Kafiri // Norsk Tidsskrift for Sprogvidenskap. Bd. XIII. Oslo, 1945.

Morgenstierne 1947 - Morgenstierne G. Some Features of Khowar Morphology // Norsk Tidsskrift for Sprogvidenskap. Bd. XIV. Oslo, 1947. P. 5-28.

Morgenstierne 1950 - Morgenstierne G. Notes on Gawar-Bati. Skrifter utgitt av Det Norske Videnskaps Akademi i Oslo. II. Hist. - Filos. Klasse, 1950, No. 1, Oslo, 1950.

Morgenstierne 1956 - Morgenstierne G. Indo-Iranian Frontier Languages. Vol III: The Pashai Language, pt. 3, Vocabulary. Oslo: Aschenoug \& Co., 1956. 238 p.

Morgenstierne 1961 - Morgenstierne G. Dardic and Kafir Languages // The Encyclopedia of Islam. Vol. 2, Fasc. 25. Leiden, Brill, 1961.

Morgenstierne 1967 - Morgenstierne G. Indo-Iranian Frontier Languages. Vol. III. The Pashai Language. 1. Grammar. Oslo: Universitetsforlaget, 1967. 337 pp.

Morgenstierne 1973 - Morgenstierne G. Indo-Iranian Frontier Languages. Vol. IV. The Kalasha Language. Oslo: Universitetforlaget, 1973. $238 \mathrm{p}$.

Morgenstierne $1973_{2}$ - Morgenstierne G. Sanscritic Words in Khowar // Irano-Dardica. Wiesbaden: Dr. Ludwig Reichert Verlag, 1973. P. 256-272.

NEVP - A New Etymological Vocabulary of Pashto by Georg Morgenstierne. Compiled and Edited by J. Elfenbein, D.N. MacKenzie and Nicholas Sims-Williams. Wiesbaden: Dr. Ludwig Reichert Verlag, 2003.

Online Torwali Dictionary 2011 - Center for Language Engineering. Online Torwali Dictionary. http://www.cle.org.pk/software/ling_resources/otd.htm

Pokorny 1959 - Pokorny J. Indogermanisches etymologisches Wörterbuch. Bern-München: Francke Verlag, 1959.

Strand 1973 - Strand R. F. Notes on Nuristani and Dardic Languages // Journal of the American Oriental Society. Vol. 93, No. 3, New Haven, 1973.

Strand 2006 - Strand R. F. Phylogenetic Classification of the Region's Languages. http://nuristan.info/lngIndex0.html

Trail, Cooper 1999 - Kalasha Dictionary with English and Urdu compiled by R. L. Trail, G. R. Cooper. Islamabad: National Institute of Pakistan Studies, Quaidi-iAzam University, Summer Institute of linguistics, 1999.

Woolner 1917 - Woolner A. C. Introduction to Prakrit. Calcutta, 1917.

Zoller 2005 - Zoller C. P. A Grammar and Dictionary of Indus Kohistani. Volume 1: Dictionary. Berlin - New-York: Mouton de Gruyter, 2005.

Anton Kogan. Some issues of the genealogical classification of the Dardic languages based on historical phonology.

Until recently, the genetic classification of Dardic languages has remained unclear in many respects. One of the questions that has not yet received a convincing answer is the existence of a separate East Dardic branch. A recent study of East Dardic lexical data by means of a modernized version of the lexicostatistical method has shown that East Dardic languages undoubtedly constitute a genetically valid linguistic entity. In the present paper an attempt is made to establish historical phonological innovations that would be common to all of them. In particular, the author has successfully revealed a bundle of four isoglosses that clearly distinguish East Dardic from the rest of the Dardic group. Although some of these isoglosses also involve other languages of the area, namely Indo-Aryan and Iranian, the whole bundle is not found anywhere outside East Dardic.

Keywords: language classification, historical phonology, Dardic languages, Aryan languages. 
